\title{
The Slovak Spa Industry and Spa Companies: Financial and Economic Situation
}

\author{
Róbert Štefko \\ University of Prešov, Faculty of Management, Prešov, Slovakia \\ Sylvia Jenčová \\ University of Prešov, Faculty of Management, Prešov, Slovakia \\ Petra Vašaničová \\ University of Prešov, Faculty of Management, Prešov, Slovakia
}

Received: 27 January 2020. Revision received: 6 May 2020. Accepted: 9 May 2020

\begin{abstract}
Slovak spa companies significantly contribute to tourism support and to health tourism development. The paper aims to evaluate the financial situation and financial position of 21 Slovak spa companies, and the Slovak spa industry within NACE 86 - Human Health Activities and NACE 869 - Other Human Health Activities. In terms of legal form, the research sample consists of 16 joint-stock companies (Inc. (a.s.)), 3 limited liability companies (Ltd. (s.r.o.)), and 2 state-owned companies (s.o.). Data of given spa companies are obtained from their Financial Statements in Register of Financial Statements of the Ministry of Finance of the Slovak Republic. Data on mean values of the financial indicators for NACE 86 and NACE 869 were obtained from the company CRIF - Slovak Credit Bureau. We cover the period 2007-2018. Our results include an evaluation of the criterion of economic efficiency of the industry NACE 86, the sub-industry NACE 869, and individual spa companies using methods of quantifying the impact of determining factors. At the same time, we present the factors that influence development most. We determine the position of spa companies by using multidimensional scaling (MDS). Results show that the total assets turnover ratio and return on sales are contributing factors to the change of ROE to the greatest extent. MDS quantifies that Spa Bojice, a.s., has the best financial position in space, on the other hand, Specialized Medical Institute Marína, s.o., has the worst position.
\end{abstract}

Key Words: spa, industry, companies, financial analysis, Slovakia.

JEL Classification: Z31, Z33.

Reference: Štefko, R., Jenčová, S. \& Vašaničová, P. (2020). The Slovak Spa Industry and Spa Companies: Financial and Economic Situation. Journal of Tourism and Services, 20(11), 28-43. doi: 10.29036/jots.v11i20.137

\section{Introduction}

The Slovak spa industry is a cultural and historical phenomenon in the Central European area. The issue of spa tourism, as one of the oldest and most important types of tourism, is increasingly discussed among leading experts and is of interest in the field of health care. Spa tourism significantly contributes to overall tourism; therefore, it is important to dedicate to study this area. The importance of tourism is evident in several areas. Its contribution the GDP of countries is not negligible, in some cases it even forms the main part of the country's income (Košíková and Loumová, 2019b). Spa tourism brings employment in the region, revenue to the state and local government, is an element of improving the health of the population, encourages the arrival of tourists, it increases the country's 


\section{JOURNAL OF TOURISM AND SERVICES}

Issue 20, volume 11, ISSN 1804-5650 (Online)

www.jots.cz

credit. The offer of spa tourism services is rich and reflected on consumer behaviour (BendaProkeinová et al., 2017).It is therefore important to pay attention to this form of tourism at all levels and to promote its development. Spa tourism is subject to globalization and must, therefore, follow trends and continually adapt to the new requirements of potential clients. To increase profitability, all spa companies have to practice active marketing in both the Slovak market and foreign markets to attract as many foreign clients as possible. An ideal solution would be an increasing number of selfpayers. Individual companies should continue to invest, refurbish hotels, focus on expanding services and focus primarily on innovation. Spa companies with a reported loss need to stabilize this unfavorable economic situation.

Slovakia is an ideal place for spa care and health tourism, offering up to 94 places with thermal and healing springs. Thanks to 21 spas with unique conditions, the Slovak Republic is one of the most advanced European countries in the spa industry. According to the data of the Statistical Office of the Slovak Republic and Ministry of Transport and Construction of the Slovak Republic, in 2017, the number of arrivals to the Slovak spa facilities was 311,138 , while foreign visitors created $20.21 \%$. In 2017, the index of total arrivals reached 1.11, in compare with 2013, and the growth rate was $11.74 \%$. The revenues were 155.31 million $€$. Taking into account the average length of overnight stay of domestic and foreign visitors in 2017, Slovakia (9.1) anticipated the Czech Republic (7.7). For 2019, it is expected that the number of spa visitors will be increased by domestic visitors due to new support measures in the field of tourism, in particular through the introduction of holiday vouchers (Jenčová and Vašaničová, 2019).

According to Kerekeš (2014, 2018), spa tourism applies natural quality water and suitable climatic conditions. Increasing the knowledge of healthy natural mineral water, alternative medicine, and building spa places has a contribution to the fact that the beginning of spa tourism can be dated back to the last centuries. New technology enabling the construction of spa wellness facilities, thermal pools, aqua parks, natural and built swimming pools also contributes significantly to the development of spa tourism. The development of new types of facilities and their equipment ensures and makes faster the regeneration and relaxation of the tourist. Moreover, the mentioned author describes the importance and contribution of spa tourism for Slovakia.

Determining the contribution of spa tourism to financial and economic development is important in developing effective management strategies in terms of sustainable economic growth (Jašková, 2019). Therefore, the aim of this paper is to evaluate the financial situation and financial position of 21 Slovak spa companies, and the Slovak spa industry within industry NACE 86 - Human Health Activities and sub-industry NACE 869 - Other Human Health Activities.

The remainder of the paper is structured as follows. Section 2 consists of literature review. Section 3 presents the data and methodology. Section 4 discusses results and Section 5 concludes.

\section{Literature review}

Slovak thermal and mineral springs have been known since the prehistory (Cuka and Rachwal, 2013), therefore, exploring various attributes in the field of the Slovak spa industry is of great importance in literature. Tourism occupies a significant position in service sector that has held the dominant position in the Slovak economy (Onuferová, Čabinová, Dzurov Vargová, 2020; Pauhofova et al., 2018). Spa companies offer a wide range of services, therefore, in the existing literature, there are some researches connected with visitor's satisfaction with providing services. Among the Slovak spa companies, Košíková and Šenková (2019) examined, through a questionnaire survey and Kruskal Wallis ANOVA, visitor's satisfaction with selected spa services, such as accommodation and food services, health care, tourism services, cultural and social services, sport and recreational services. Overall, the high quality of the provided spa services and the high visitor satisfaction were proved. Kasagranda and 


\section{JOURNAL OF TOURISM AND SERVICES}

Issue 20, volume 11, ISSN 1804-5650 (Online)

www.jots.cz

Gurńák (2017) provided geographical analysis of Slovak spa and wellness tourism and categorized spa resorts according to their international (Bardejov Spa, Slovak Health Spa Piešt'any), national (Spa Bojnice, Spa Sliač, Spa Dudince, Spa Trenčianske Teplice, Slovak Health Spa Turčianske Teplice, Slovak Health Spa Rajecké Teplice), regional (Spa Nimnica, Spa Vyšné Ružbachy, Spa Nový Smokovec, Spa Brusno), and local (Spa Horný Smokovec, Spa Lučivná, Spa Červený Kláštor etc.) importance.

Moreover, attention is also paid to the financial side of the Slovak spa companies. Jenčová, Litavcová, Vašaničová (2017) noted that in the area of financial decision making and modeling, theoretical knowledge and application of statistical characteristics in the practice of business entities are one of the basic facilities of each financial manager. As is stated in Gallo et al. (2018), financial indicators has leading position among all individual indicators using to evaluate situation of the company. The importance of financial indicators in predicting the future financial situation and corporate stability is portrayed in the research of Kovacova et al (2018) or Kliestik et al. (2018).

Jenčová, Vašaničová, Petruška (2019) analyzed the financial and economic position of the Slovak spa companies in the period 2013-2017, by using methods of multi-criteria evaluation. The authors chose financial ratios as criteria, specifically ROA, ROS, the ratio of personal costs to net turnover, the ratio of added value to sales. The results of the financial analysis, in which they use four methods of multi-criteria evaluation (ranking method, scoring method, method of normed shape, and method of distance from fictitious object), shows that the best position has Spa Bojnice, a.s., Spa Lúčky, a.s., Spa Dudince, a.s., Bardejov Spa, a.s., and Slovak Health Spa Piešt'any, a.s. In 2017, the least competitive was Spa Štós, a.s.; Spa Červený Kláštor Smerdžonka, PIENINY RESORT, s.r.o.; Natural Iodine Spa Č́̌ž, a.s.; Spa Brusno, a.s.

Using models of multiple regression analysis and production function that is the equivalent of the Cobb-Douglas function, Jenčová et al. (2018) quantified coefficient of competitiveness for each of the spa companies operating in Slovakia. The authors assessed the concentration rate through the Gini Index of Concentration that quantifies the growth of the share of the spa company on the market and hence the hierarchical status on the market. By modeling the volume of sales from the personal costs and the amount of assets, the results of the analysis showed that during the period 2015-2016, Slovak medical spa Rajecké Teplice, a.s., (1.0), Spa Nimnica, a.s., (0.942), Slovak Health Spa Turčianske Teplice, a.s. (0.911), Spa Nový Smokovec, a.s. (0.886), Bardejov Spa, a.s. (0.848), Spa Bojnice, a.s. (0.749), Spa Lúčky, a.s. (0.723) were the most competitive spa. Natural Iodine Spa Cíž, a.s. (0.275), Spa Sliač, a.s. (0.243), Spa Brusno, a.s. (0.074) belong into the less competitive companies. The figures in the brackets indicate the achieved coefficient of competitiveness for the given spa company.

Briefly, there exist many other kinds of research that deal with Slovak spas as a whole industry or individual spa companies. The Slovak spa companies was also evaluated by using multidimensional scaling, while results of Litavcová et al. (2018) showed that Spa Bojnice, a.s., Spa Lúčky, a.s. have dominant position among all spas in Slovakia. Cabinová and Onuferová (2019a, 2019b) evaluated the performance and efficiency of the Slovak medical spa industry during 2012-2017 by using EVA (economic value added) indicator, the simplex method, and PPE model, while their results place Spa Bojnice, a.s. first among all examined spa companies. Kučerova (2013) addressed her research on the impact of the economic crisis on spa companies. Results showed that the crisis has less influenced spa companies than other accommodation establishments. Košíková and Loumová (2019a) studied development of revenues from the Slovak spa accommodation establishments in the period 2005-2017, and they compare results of domestic visitors to these of foreign visitors. Revenues from the accommodation of domestic visitors have the most stable development.

\section{Methods}

\subsection{Data}




\section{JOURNAL OF TOURISM AND SERVICES}

Issue 20, volume 11, ISSN 1804-5650 (Online)

www.jots.cz

To assess the financial and economic position of the Slovak spa companies, we use data of 21 spa companies connected with their revenues, which are obtained from the Register of Financial Statements of the Ministry of Finance of the Slovak Republic. In terms of legal form, the research sample consists of 16 joint-stock companies (Inc. (a.s.)), 3 limited liability companies (Ltd. (s.r.o.)), and 2 state-owned companies (s.o.). We cover the period 2013-2018. Specifically, we use following financial indicators: return on equity $(R O E)$, return on assets $(R O A)$, return on sales (ROS), total assets turnover ratio (TA), financial leverage (FL) (Zimon, 2018; Vrbka, et al., 2019). Moreover, to assess selected financial indicators of the Slovak decision-making units within the NACE 86 (Human Health Activities), and NACE 869 (Other Human Health Activities), we use data of mean values of these indicators obtained from the company CRIF - Slovak Credit Bureau for the period 2007-2018.

Table 1 gives the specific focus of the Slovak spa companies on individual diagnoses according to the NUTS III classification.

Table 1. Spa companies in the Slovak Republic

\begin{tabular}{|c|c|}
\hline Spa company & Focus of the spa company \\
\hline $\begin{array}{l}\text { Bardejov Spa, a.s. } \\
\text { (Presov Region) }\end{array}$ & $\begin{array}{l}\text { Oncological diseases, diseases of the circulatory system, digestive diseases, } \\
\text { diseases of metabolism disorder and glands with internal secretion, } \\
\text { nontuberculous airway diseases, locomotory diseases, kidney and urinary } \\
\text { tract diseases, gynecological diseases, occupational diseases }\end{array}$ \\
\hline $\begin{array}{l}\text { Spa Horný Smokovec, s.r.o. } \\
\text { (Presov Region) }\end{array}$ & Nontuberculous airway diseases \\
\hline $\begin{array}{l}\text { Spa Lučivná, a.s. } \\
\text { (Presov Region) }\end{array}$ & Nontuberculous airway diseases \\
\hline $\begin{array}{l}\text { Spa Nový Smokovec, a.s. } \\
\text { (Presov Region) }\end{array}$ & $\begin{array}{l}\text { Diseases of metabolism disorder and glands with internal secretion, } \\
\text { nontuberculous airway diseases, mental illnesses, occupational diseases }\end{array}$ \\
\hline $\begin{array}{l}\text { Spa Vyšné Ružbachy, a.s. } \\
\text { (Presov Region) }\end{array}$ & $\begin{array}{l}\text { Oncological diseases, diseases of the circulatory system, digestive diseases, } \\
\text { diseases of metabolism disorder and glands with internal secretion, kidney } \\
\text { and urinary tract diseases, mental illnesses, female diseases, occupational } \\
\text { diseases }\end{array}$ \\
\hline $\begin{array}{l}\text { Spa Červený Kláštor } \\
\text { Smerdžonka } \\
\text { PIENINY RESORT, s.r.o. } \\
\text { (Presov Region) }\end{array}$ & Skin diseases \\
\hline $\begin{array}{l}\text { Spa Lúčky, a.s. } \\
\text { (Zilina Region) }\end{array}$ & $\begin{array}{l}\text { Oncological diseases, nerve diseases, locomotory diseases, female diseases, } \\
\text { occupational diseases }\end{array}$ \\
\hline $\begin{array}{l}\text { Slovak Health Spa Rajecké } \\
\text { Teplice, a.s. } \\
\text { (Zilina Region) }\end{array}$ & Nerve diseases, locomotory diseases, occupational diseases \\
\hline $\begin{array}{l}\text { Slovak Health Spa Turčianske } \\
\text { Teplice, a.s. } \\
\text { (Zilina Region) }\end{array}$ & $\begin{array}{l}\text { Oncological diseases, digestive diseases, nerve diseases, locomotory diseases, } \\
\text { kidney and urinary tract diseases, female diseases, occupational diseases }\end{array}$ \\
\hline $\begin{array}{l}\text { Spa Bojnice, a.s. } \\
\text { (Trencin Region) }\end{array}$ & $\begin{array}{l}\text { Nerve diseases, locomotory diseases, kidney and urinary tract diseases, } \\
\text { female diseases, occupational diseases }\end{array}$ \\
\hline $\begin{array}{l}\text { Spa Nimnica, a.s. } \\
\text { (Trencin Region) }\end{array}$ & $\begin{array}{l}\text { Oncological diseases, diseases of the circulatory system, digestive diseases, } \\
\text { diseases of metabolism disorder and glands with internal secretion, } \\
\text { nontuberculous airway diseases, nerve diseases, locomotory diseases, female } \\
\text { diseases, occupational diseases }\end{array}$ \\
\hline $\begin{array}{l}\text { Spa Trenčianske Teplice, a.s. } \\
\text { (Trencin Region) }\end{array}$ & $\begin{array}{l}\text { Occupational diseases, digestive diseases, diseases of metabolism disorder } \\
\text { and glands with internal secretion, nerve diseases locomotory diseases, skin } \\
\text { diseases, female diseases, occupational diseases }\end{array}$ \\
\hline
\end{tabular}




\section{JOURNAL OF TOURISM AND SERVICES}

Issue 20, volume 11, ISSN 1804-5650 (Online)

www.jots.cz

\begin{tabular}{|c|c|}
\hline $\begin{array}{l}\text { Spa Štós, a.s. } \\
\text { (Kosice Region) }\end{array}$ & $\begin{array}{l}\text { Oncological diseases, diseases of metabolism disorder and glands with } \\
\text { internal secretion, nontuberculous airway diseases, mental illnesses, female } \\
\text { diseases, occupational diseases }\end{array}$ \\
\hline $\begin{array}{l}\text { Slovak Health Spa Piešt'any, a.s. } \\
\text { (Trnava Region) }\end{array}$ & Nerve diseases, locomotory diseases, occupational diseases \\
\hline $\begin{array}{c}\text { Spa Brusno, a.s. } \\
\text { (Banska Bystrica Region) }\end{array}$ & $\begin{array}{l}\text { Diseases of the circulatory system, digestive diseases, diseases of metabolism } \\
\text { disorder and glands with internal secretion, occupational diseases }\end{array}$ \\
\hline $\begin{array}{l}\text { Natural Iodine Spa Cíž, a.s. } \\
\text { (Presov Region) }\end{array}$ & $\begin{array}{l}\text { Nontuberculous airway diseases, nerve diseases, locomotory diseases, } \\
\text { gynecological diseases }\end{array}$ \\
\hline $\begin{array}{c}\text { Spa Dudince, a.s. } \\
\text { (Banska Bystrica Region) }\end{array}$ & $\begin{array}{l}\text { Diseases of the circulatory system, nerve diseases, locomotory diseases, } \\
\text { occupational diseases }\end{array}$ \\
\hline $\begin{array}{l}\text { Spa Kováčová, s.r.o. } \\
\text { (Banska Bystrica Region) }\end{array}$ & $\begin{array}{l}\text { Digestive diseases, diseases of metabolism disorder and glands with internal } \\
\text { secretion, nerve diseases, locomotory diseases, kidney and urinary tract } \\
\text { diseases, female diseases, oncological diseases }\end{array}$ \\
\hline $\begin{array}{c}\text { Spa Sliač, a.s. } \\
\text { (Banska Bystrica Region) }\end{array}$ & $\begin{array}{l}\text { Oncological diseases, diseases of the circulatory system, locomotory diseases, } \\
\text { female diseases }\end{array}$ \\
\hline
\end{tabular}

Source: own processing according to Matlovičová, Kolesarová, Židová, 2013

\subsection{Methodology}

In the sub-industry NACE 869 - Other Human Health Activities, methods of quantification of determining factors are applied only marginally. To assess the financial health of the Slovak spa industry, several authors applied other methods, which they implemented to the area of financial and economic analysis while they took into account financial ratios. For example,

In this paper, we emphasize the application of mathematical methods, through which it is possible to quantify financial ratios, which are most important for owners, managers or other external entities. Štefko et al. (2017) used similar methods in the case of state and private hospitals.

According to Jenčová (2016), and Zmeškal, Dluhošová, Tichý (2013), we quantify the influence of determining factors by application logarithmic method (1), (2), (3), incremental method (4), (5), (6), index method (7), (8), (9), and functional method (10)-(16) within the comparison of the influences. In formula (10), $R_{a j}=\Delta a_{j} / a_{j 0}$, and $R_{x}=\Delta x / x_{0}$, where $R_{a j}, R_{x}$ mean discrete revenue, $a_{j}$ is analytical factor, $x$ is the synthetic indicator, and $x_{0}, a_{j 0}$ are the basic values of analyzed indicator (Jenčová, Vašaničová, Litavcová, 2019).

$$
\begin{gathered}
\triangle R O E_{\triangle R O S}=\frac{\log \frac{R O S_{1}}{R O S_{0}}}{\log \frac{R O E_{1}}{R O E_{0}}} \cdot\left(R O E_{1}-R O E_{0}\right)=\frac{\log I_{R O S}}{\log \frac{R O S_{1}}{R O S_{0}}+\log \frac{T A_{1}}{T A_{0}}+\log \frac{F L_{1}}{F L_{0}}} \cdot \Delta R O E \\
\Delta R O E_{\triangle T A}=\frac{\log \frac{T A_{1}}{T A_{0}}}{\log \frac{R O E_{1}}{R O E_{0}}} \cdot\left(R O E_{1}-R O E_{0}\right)=\frac{\log I_{T A}}{\log \frac{R O S_{1}}{R O S_{0}}+\log \frac{T A_{1}}{T A_{0}}+\log \frac{F L_{1}}{F L_{0}}} \cdot \Delta R E \\
\Delta R O E_{\triangle F L}=\frac{\log \frac{F L_{1}}{F L_{0}}}{\log \frac{R O E_{1}}{R O E_{0}}} \cdot\left(R O E_{1}-R O E_{0}\right)=\frac{\log I_{F L}}{\log \frac{R O S_{1} \cdot T A_{1} \cdot F L_{1}}{R O A_{0} \cdot F L_{0}}} \cdot \Delta R E \\
\Delta R O E_{\rightarrow \triangle(R O S)}=\left(R O S_{1}-R O S_{0}\right) \cdot T A_{0} \cdot F L_{0} \\
\Delta R O E_{\rightarrow \triangle(T A)}=R O S_{0} \cdot\left(T A_{1}-T A_{0}\right) \cdot F L_{0} \\
\Delta R O E_{\rightarrow \triangle(F L)}=R O S_{0} \cdot O A_{0} \cdot\left(F L_{1}-F L_{0}\right) \\
\Delta R O E_{\rightarrow \triangle(R O S)}^{=}\left(R O S_{1} \cdot T A_{0} \cdot F L_{0}\right)-\left(R O S_{1} \cdot T A_{0} \cdot F L_{0}\right)
\end{gathered}
$$




\section{JOURNAL OF TOURISM AND SERVICES}

Issue 20, volume 11, ISSN 1804-5650 (Online)

www.jots.cz

$$
\begin{aligned}
& \triangle R O E_{\rightarrow \triangle(T A)}=\left(R O S_{1} \cdot T A_{1} \cdot F L_{0}\right)-\left(R O S_{1} \cdot T A_{0} \cdot F L_{0}\right) \\
& \Delta R O E_{\rightarrow \Delta(F L)}=\left(R O S_{1} \cdot T A_{1} \cdot F L_{1}\right)-\left(R O S_{1} \cdot T A_{1} \cdot F L_{0}\right)
\end{aligned}
$$

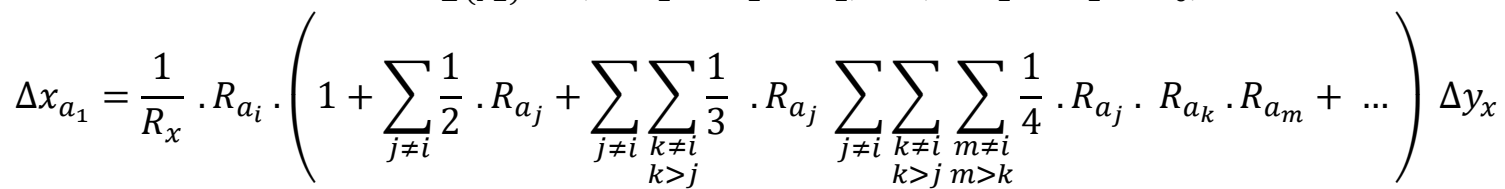

$$
\begin{aligned}
& \triangle R O E_{R O S}=R O E_{0} \cdot \frac{\Delta R O S}{R O S_{0}} \cdot\left(1+\frac{\frac{\Delta F L}{F L_{0}}+\frac{\Delta T A}{T A_{0}}}{2}+\frac{\frac{\Delta F L}{F L_{0}} \cdot \frac{\Delta T A}{T A_{0}}}{3}\right) \\
& \triangle R O E_{R O S}=\frac{1}{R_{x}} \cdot R_{R O S} \cdot\left(1+\frac{1}{2} \cdot R_{T A}+\frac{1}{2} \cdot R_{F L}+\frac{1}{3} \cdot R_{T A} \cdot R_{F L}\right) \Delta y_{x} \\
& \Delta R O E_{F L}=R O E_{0} \cdot \frac{\Delta F L}{F L_{0}} \cdot\left(1+\frac{\frac{\Delta R O S}{R O S_{0}}+\frac{\Delta T A}{T A_{0}}}{2}+\frac{\frac{\Delta R O S}{R O S_{0}} \cdot \frac{\Delta T A}{T A_{0}}}{3}\right) \\
& \triangle R O E_{F L}=\frac{1}{R_{x}} \cdot R_{a_{3}} \cdot\left(1+\frac{1}{2} \cdot R_{a_{1}}+\frac{1}{2} \cdot R_{a_{2}}+\frac{1}{3} \cdot R_{a_{1}} \cdot R_{a_{2}}\right) \Delta y_{x} \\
& \Delta R O E_{T A}=R O E_{0} \cdot \frac{\Delta T A}{T A_{0}} \cdot\left(1+\frac{\frac{\Delta R O S}{R O S_{0}}+\frac{\Delta F L}{F L_{0}}}{2}+\frac{\frac{\Delta F L}{F P_{0}} \cdot \frac{\Delta R O S}{R O S_{0}}}{3}\right) \\
& \Delta R O E_{T A}=\frac{1}{R_{x}} \cdot R_{a_{2}} \cdot\left(1+\frac{1}{2} \cdot R_{a_{1}}+\frac{1}{2} \cdot R_{a_{3}}+\frac{1}{3} \cdot R_{a_{1}} \cdot R_{a_{3}}\right) \Delta y_{x}
\end{aligned}
$$

The position of the spa companies in space is determined by multidimensional scaling (MDS) using SPSS software (algorithm PROXSCAL). The goal of MDS is to reduce the data dimension and study object relationships in a reduced space. Multidimensional scaling allows the analyzed objects to be displayed in a plane (space) to maintain the original distance (difference) between them. It allows us to create a map that records objects with similar values close to each other and objects with different values farther apart while maintaining the original distance. The display of objects in the plane is then clear and easy to read (Petruška, 2017).

Next, we use Kruskal's Stress (Standardized Residual Sum of Square) that is an analogy of the coefficient of determination for multiple regression. The formula is given by (17), where $d_{i j}$ is the Euclidean distance, and $\hat{d}_{i j}$ is the predicted distance achieved by the MDS model, the value of which depends on the number of dimensions achieved and the algorithm used (Kruskal and Carmone, 1967). The stress value around 0.2 indicates poor goodness of fit; 0.1 means fair goodness of fit; 0.05 is good fit; 0.025 is excellent fit, and 0.00 represents perfect goodness of fit. Acceptable values of stress depend on the quality of the distance proximity matrix and the number of objects in that matrix. Meloun et al. (2017) detailed the steps of quantifying the MDS method.

$$
\text { stress }=\sqrt{\frac{\sum_{k=1}^{m}\left(d_{i j}-\widehat{d_{l j}}\right)^{2}}{\sum_{k=1}^{m}\left(d_{i j}-\bar{d}\right)^{2}}}
$$

\section{Results and Discussion}

4.1. Linkages between Productivity Indicators of the Other Human Health Activities and Spa Companies 


\section{JOURNAL OF TOURISM AND SERVICES}

Issue 20, volume 11, ISSN 1804-5650 (Online)

www.jots.cz

Financial ratios play an important role in assessing corporate financial soundness (Kliestik et al., 2020). Table 2 presents the ratios of the spa company's productivity indicators to the NACE 869 industry's indicator. Specifically, it is the ratio of the spa company's basic earning power $\left(\mathrm{RO} A_{\text {company }}\right)$ to the industry's basic earning power $\left(R O A_{\text {industry }}\right)$, and ratio of added value $(A V)$ to sales $(S)$ in relation to the industry. The median of total liquidity reaches values within the recommended interval for total liquidity. In 2018, spa companies waited an average of 46 days to collect their claims. This is a decrease of 12 days compared to 2014. A creditors payment period (86 days) exceeded an average collection period. The overall indebtedness in the industry is $45 \%$. In 2018 , according to the ratio of $R O A_{\text {company }}$ to $\mathrm{RO} A_{\text {industy }}$, Spa Nimnica, a.s., ranked first, and Spa Bojnice, a.s., ranked second; according to the ratio $(A V / S)_{\text {company }} /(A V / S)_{\text {industry }}$ Specialized Medical Institute Marína, s.o., ranked first, and Spa Bojnice, a.s. ranked second. In both cases, Spa Sliač, a.s. ranked in the last places.

Table 2. Ratios of the spa company's productivity indicators to the NACE 869 industry's indicators

\begin{tabular}{|c|c|c|c|c|c|c|c|c|c|c|c|c|}
\hline \multirow{2}{*}{ Spa company } & \multicolumn{6}{|c|}{$R O A_{\text {company }} / R O A_{\text {industry }}$} & \multicolumn{6}{|c|}{$(A V / S)_{\text {company }} /(A V / S)_{\text {industry }}$} \\
\hline & 2013 & 2014 & 2015 & 2016 & 2017 & 2018 & 2013 & 2014 & 2015 & 2016 & 2017 & 2018 \\
\hline $\begin{array}{l}\text { Slovak Health Spa } \\
\text { Piešt'any, a.s. }\end{array}$ & 1.476 & 0.71 & 0.620 & 0.263 & 0.594 & 0.630 & 1.289 & 1.263 & 1.185 & 1.177 & 1.244 & 1.210 \\
\hline $\begin{array}{l}\text { Slovak Health Spa } \\
\text { Turčianske Teplice, a.s. }\end{array}$ & 0.930 & 0.65 & 0.455 & 0.312 & 0.223 & -0.421 & 0.810 & 0.861 & 0.846 & 0.887 & 0.919 & 0.826 \\
\hline $\begin{array}{l}\text { Slovak Health Spa Rajecké } \\
\text { Teplice, a.s. }\end{array}$ & 1.099 & 0.23 & 0.751 & 0.914 & 0.674 & 0.552 & 0.942 & 1.007 & 0.841 & 0.914 & 0.806 & 0.788 \\
\hline Bardejov Spa, a.s. & 3.014 & 0.61 & 1.153 & 0.441 & 0.880 & 1.489 & 1.105 & 0.972 & 1.156 & 1.010 & 1.041 & 1.056 \\
\hline $\begin{array}{l}\text { Spa Trenčianske Teplice, } \\
\text { a.s. }\end{array}$ & 0.553 & 0.15 & 0.128 & 0.132 & 0.142 & 0.192 & 1.180 & 1.103 & 0.982 & 0.890 & 0.931 & 1.002 \\
\hline Spa Bojnice, a.s. & 1.674 & 2.05 & 1.593 & 0.000 & 1.508 & 1.589 & 1.241 & 1.394 & 1.285 & 1.400 & 1.397 & 1.355 \\
\hline Spa Dudince, a.s. & 1.485 & 0.6 & 0.373 & 0.643 & 0.923 & 0.964 & 1.217 & 1.215 & 1.165 & 1.260 & 1.352 & 1.277 \\
\hline Spa Lúčky, a.s. & 0.789 & 1.04 & 1.368 & 1.098 & 1.196 & 0.276 & 1.214 & 1.280 & 1.223 & 1.244 & 1.289 & 1.177 \\
\hline Spa Nimnica, a.s. & 1.003 & 0.27 & -0.051 & 0.450 & 1.362 & 1.961 & 0.967 & 0.934 & 0.841 & 0.914 & 1.085 & 1.128 \\
\hline $\begin{array}{l}\text { Specialized Medical } \\
\text { Institute Marína, s.o. }\end{array}$ & 2.767 & 1.21 & 1.015 & 0.816 & 0.738 & 0.639 & 1.526 & 1.460 & 1.438 & 1.483 & 1.962 & 1.875 \\
\hline Spa Vyšné Ružbachy, a.s. & -0.487 & -0.3 & -0.109 & 0.034 & 0.167 & 0.021 & 1.000 & 0.949 & 1.038 & 1.082 & 1.165 & 1.089 \\
\hline Spa Brusno, a.s. & 0.541 & -0.2 & -0.675 & -5.574 & -0.489 & -0.050 & 0.992 & 0.706 & 0.941 & 1.016 & 0.954 & 0.996 \\
\hline $\begin{array}{l}\text { Slovthermae Spa Diamant, } \\
\text { Dudince, s.o. }\end{array}$ & 0.585 & 0.41 & 0.016 & -0.362 & 0.027 & -0.421 & 1.284 & 1.280 & 1.213 & 1.209 & 1.287 & 1.127 \\
\hline Spa Lučivná, a.s. & 8.696 & 0.45 & 0.338 & -0.333 & 0.411 & 0.806 & 1.179 & 1.292 & 1.189 & 1.217 & 1.193 & 1.231 \\
\hline Spa Sliač, a.s. & -7.807 & -2.1 & -1.333 & -1.376 & -1.949 & -2.417 & 0.578 & 0.838 & 0.959 & 0.993 & 0.987 & 0.879 \\
\hline Spa Nový Smokovec, a.s. & 1.130 & 0.41 & 0.339 & 0.305 & 0.204 & 0.307 & 0.946 & 1.024 & 1.122 & 1.045 & 1.066 & 1.072 \\
\hline Natural Iodine Spa Cíž, a.s. & -0.450 & 0.31 & -0.174 & -1.400 & -1.176 & -1.439 & 1.143 & 1.125 & 1.074 & 1.017 & 1.086 & 1.061 \\
\hline Spa Štós, a.s. & 3.979 & 1.32 & 0.440 & 0.528 & -1.671 & -0.971 & 1.330 & 1.273 & 1.132 & 1.210 & 1.161 & 1.201 \\
\hline Spa Kováčová, s.r.o. & 2.808 & 1.02 & 0.614 & 0.499 & -0.937 & 0.153 & 1.478 & 1.386 & 1.278 & 1.346 & 1.257 & 1.250 \\
\hline Spa Horný Smokovec, s.r.o. & 1.514 & 1.13 & 0.480 & 0.450 & 1.510 & 1.285 & 1.037 & 0.076 & 0.971 & 1.017 & 1.125 & 1.103 \\
\hline PIENINY RESORT, s.r.o. & -1.048 & -0.6 & -0.193 & -0.283 & -0.226 & -0.164 & 0.608 & 0.656 & 0.807 & 0.650 & 0.718 & 0.911 \\
\hline
\end{tabular}

Source: own calculations

According to available data for individual spa companies, during each analysed period, the Slovak spa industry employs nearly 4,000 people. In the first place, according to employment (908 employees), added value (23.737 M €), volume of sales (36.782 M €), number of visitors $(44,898)$, and number of beds $(2,400)$, are Slovak Health Spa Piešt'any, a.s. Spa Bojnice, a.s. is, clearly, one of the spa companies with higher profitability because, in 2018, one euro of equity generated eight cents of net profit. The spa management considers the decentralization of management and regular evaluation of performance compared to the previous period to be very important. On the other hand, the Natural 


\section{JOURNAL OF TOURISM AND SERVICES}

Issue 20, volume 11, ISSN 1804-5650 (Online)

www.jots.cz

Iodine Spa Číž, a.s., PIENINY RESORT, s.r.o., Spa Brusno, a.s. (restructuring) shows a long-term loss. In recent years, Spa Kováčová, s.r.o. reports negative equity.

\subsection{Assessing the Financial Situation of the industries NACE 86 and NACE 869}

Table 3 summarizes the number of decision-making units operating in NACE 86 and NACE 869. It is evident that number of companies operating in the Slovak spa industry has increasing trend.

Table 3. The number of these decision-making units

\begin{tabular}{|c|c|c|c|c|c|c|c|c|c|c|c|c|}
\hline NACE & $\mathbf{2 0 0 7}$ & $\mathbf{2 0 0 8}$ & $\mathbf{2 0 0 9}$ & $\mathbf{2 0 1 0}$ & $\mathbf{2 0 1 1}$ & $\mathbf{2 0 1 2}$ & $\mathbf{2 0 1 3}$ & $\mathbf{2 0 1 4}$ & $\mathbf{2 0 1 5}$ & $\mathbf{2 0 1 6}$ & $\mathbf{2 0 1 7}$ & $\mathbf{2 0 1 8}$ \\
\hline $\mathbf{8 6}$ & 2,356 & 2,625 & 2,829 & 3,552 & 3,420 & 4,002 & 4,081 & 4,385 & 4,855 & 4,919 & 5,079 & 5,175 \\
\hline $\mathbf{8 6 9}$ & 153 & 175 & 183 & 237 & 202 & 238 & 245 & 247 & 253 & 266 & 284 & 256 \\
\hline \multicolumn{10}{c|}{ Source: own processing according to CRIBIS }
\end{tabular}

Figure 1 describes the development of mean values of the median, lower quartile, and upper quartile of $\mathrm{ROA}(\%)$ and $\mathrm{ROE}(\%)$ of the industry NACE 869 during the period $2007-2018$.

Figure 1. Development of mean values of ROA (\%) and ROE (\%) of the industry NACE 869

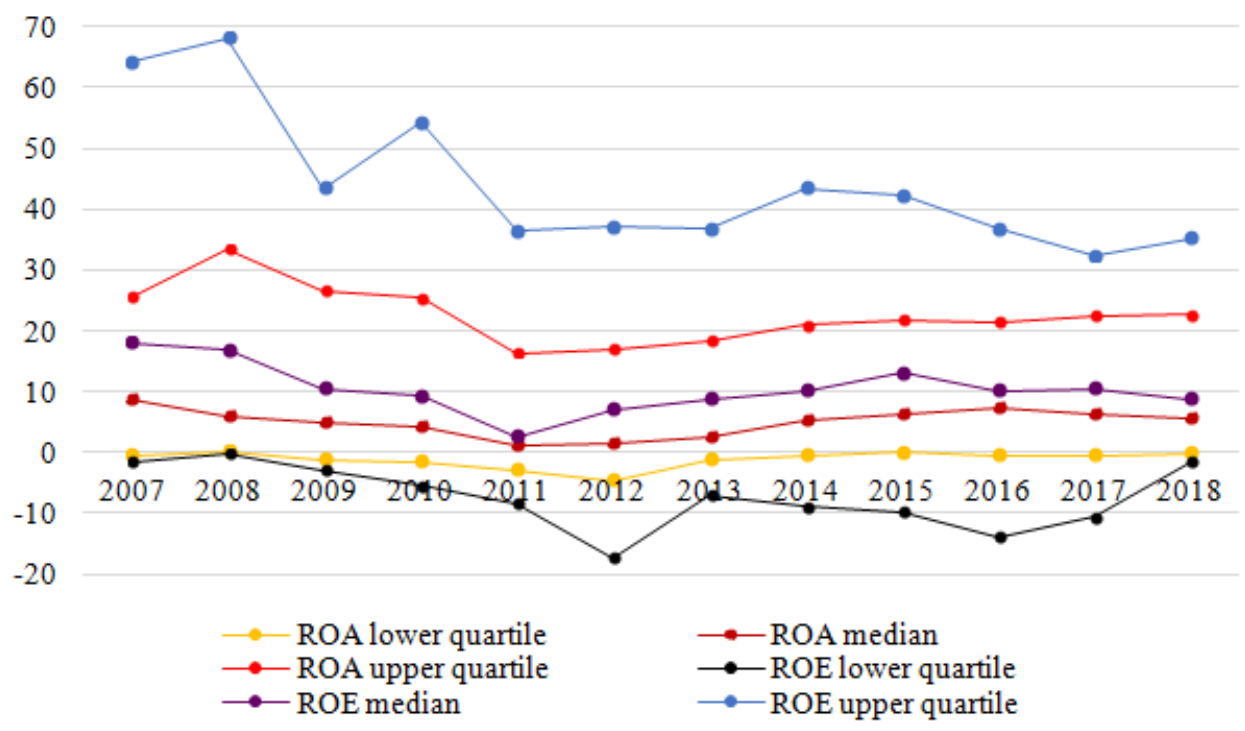

Source: own processing according to data from Slovak Credit Bureau (2007-2018)

Table 4 presents calculated mean values (lower and upper quartile) of financial indicators of the Slovak decision-making units within the NACE 86, and NACE 869.

Table 4. Lower ( $L Q)$ and upper (UQ) quartile of financial metrics within the NACE 86, and NACE 869 (ROS in \%,TA as coefficient)

\begin{tabular}{|l|c|c|c|c|c|c|c|c|c|c|c|c|}
\hline Indicator & $\mathbf{2 0 0 7}$ & $\mathbf{2 0 0 8}$ & $\mathbf{2 0 0 9}$ & $\mathbf{2 0 1 0}$ & $\mathbf{2 0 1 1}$ & $\mathbf{2 0 1 2}$ & $\mathbf{2 0 1 3}$ & $\mathbf{2 0 1 4}$ & $\mathbf{2 0 1 5}$ & $\mathbf{2 0 1 6}$ & $\mathbf{2 0 1 7}$ & $\mathbf{2 0 1 8}$ \\
\hline$L Q_{T A(86)}$ & 0.99 & 1.13 & 1.09 & 1.11 & 1.13 & 1.14 & 1.04 & 1.02 & 0.93 & 0.92 & 0.86 & 0.85 \\
\hline$L Q_{T A(869)}$ & 0.51 & 0.47 & 0.35 & 0.43 & 0.37 & 0.30 & 0.31 & 0.48 & 0.43 & 0.57 & 0.47 & 0.38 \\
\hline$U_{T} Q_{T(86)}$ & 2.20 & 2.22 & 2.18 & 2.29 & 2.38 & 2.43 & 2.30 & 2.19 & 2.16 & 2.12 & 2.05 & 2.00 \\
\hline$U Q_{T A(869)}$ & 2.68 & 2.47 & 2.29 & 2.38 & 2.54 & 2.59 & 2.37 & 2.17 & 2.18 & 2.28 & 2.13 & 2.11 \\
\hline$L Q_{\text {ROS(86) }}$ & 3.72 & 4.73 & 3.51 & 2.98 & 2.80 & 3.07 & 3.58 & 4.70 & 4.99 & 5.92 & 4.64 & 5.28 \\
\hline$L Q_{\text {ROS(869) }}$ & 0.52 & 1.73 & -0.41 & -2.74 & -8.28 & -12.24 & -0.63 & 0.14 & 0.02 & 0.27 & 0.10 & 0.42 \\
\hline
\end{tabular}




\section{JOURNAL OF TOURISM AND SERVICES}

Issue 20, volume 11, ISSN 1804-5650 (Online)

www.jots.cz

\begin{tabular}{|l|l|l|l|l|l|l|l|l|l|l|l|l|}
\hline$U Q_{\text {ROS }(86)}$ & 26.10 & 27.94 & 27.58 & 26.19 & 25.56 & 24.97 & 26.05 & 26.88 & 28.23 & 29.49 & 28.50 & 30.37 \\
\hline$U_{\text {ROS }(869)}$ & 17.66 & 21.80 & 19.20 & 18.96 & 12.73 & 13.80 & 15.53 & 19.46 & 18.27 & 16.58 & 19.70 & 17.76 \\
\hline
\end{tabular}

In this paper, we apply Du Pont model according to Štefko et al. (2017). Following financial metrics from the period 2014-2015 were entered into model: median of return on sales (ROS), total assets turnover ratio $(T A)$, financial leverage $(F L)$. DuPont equation represented the multiplicative linkage of the median of the individual factors. Based on the set of decision-making units were obtained lower quartile (LQ), and upper quartile (UQ) for NACE 86, and NACE 869 (Table 4). The development of the median for total assets turnover ratio (coefficient), financial leverage (coefficient), and $R O S(\%)$ is shown in Table 5.

Table 5. Median of financial metrics within the NACE 86, and NACE 869 in the period 2007-2018 (ROS in $\%$, FL and TA as coefficient)

\begin{tabular}{|c|c|c|c|c|c|c|c|c|c|c|c|c|}
\hline Indicator & $\mathbf{2 0 0 7}$ & $\mathbf{2 0 0 8}$ & $\mathbf{2 0 0 9}$ & $\mathbf{2 0 1 0}$ & $\mathbf{2 0 1 1}$ & $\mathbf{2 0 1 2}$ & $\mathbf{2 0 1 3}$ & $\mathbf{2 0 1 4}$ & $\mathbf{2 0 1 5}$ & $\mathbf{2 0 1 6}$ & $\mathbf{2 0 1 7}$ & $\mathbf{2 0 1 8}$ \\
\hline$M_{T A(86)}$ & 1.59 & 1.63 & 1.63 & 1.67 & 1.72 & 1.73 & 1.57 & 1.52 & 1.46 & 1.42 & 1.35 & 1.33 \\
\hline$M_{T A(869)}$ & 1.64 & 1.62 & 1.42 & 1.47 & 1.32 & 1.34 & 1.25 & 1.24 & 1.30 & 1.27 & 1.06 & 1.11 \\
\hline$M_{F L(86)}$ & 1.82 & 1.77 & 1.75 & 1.81 & 1.83 & 1.79 & 1.36 & 1.32 & 1.23 & 1.15 & 1.09 & 1.10 \\
\hline$M_{F L(869)}$ & 2.41 & 2.16 & 1.88 & 1.85 & 2.0 & 2.23 & 2.23 & 1.22 & 1.47 & 1.18 & 1.30 & 1.07 \\
\hline$M_{R O S(86)}$ & 14.25 & 15.00 & 1352 & 12.47 & 11.86 & 11.59 & 12.19 & 12.95 & 13.89 & 15.49 & 14.13 & 16.64 \\
\hline$M_{R O S(869)}$ & 7.26 & 9.52 & 6.23 & 6.08 & 2.51 & 3.27 & 4.44 & 6.75 & 6.79 & 6.81 & 7.63 & 7.32 \\
\hline
\end{tabular}

To compare the influence of financial metrics within the methods of quantification of the impact of determining factors, we provide elementary realization of the quantification of the impact of the individual components of the Du Pont equation by using incremental, logarithmic, index, and functional method. We present analytical components via return on sales (ROS), total assets turnover ratio $(T A)$, and financial leverage $(F L)$. These components are linked by a multiplicative linkage representing the first degree of pyramidal decomposition, where the economic criterion of effectiveness is given by the return on equity (ROE). In the period 2014-2015, in NACE 86, the synthetic indicator dropped by $0.96 \mathrm{pp}$. year-on-year, and the increase by $2.7 \mathrm{pp}$. was recorded in NACE 869 . In the period 2016-2017, ROE increased slightly (0.3 pp.). Individual analytical indicators in absolute terms contribute to the overall change in return on equity of the group of healthcare sector decision-making units. The impacts are calculated according to the formulas (1-16). In Table 6 and 7, we show the values of the factors affecting the change of ROE within the NACE 86 - Human Health Activities, and within the NACE 869 - Other Human Health Activities for the period 2014-2015, 2016-2017 respectively.

Table 6. Methods of quantification of the impact of determining factors within the NACE 86 and 869 (2014-2015)

\begin{tabular}{|c|c|c|c|c|c|c|c|c|}
\hline \multirow{2}{*}{$\begin{array}{l}\text { Factors } \\
\text { /NACE }\end{array}$} & \multicolumn{2}{|c|}{$\begin{array}{l}\text { Logarithmic } \\
\text { method }\end{array}$} & \multicolumn{2}{|c|}{$\begin{array}{c}\text { Index } \\
\text { method }\end{array}$} & \multicolumn{2}{|c|}{$\begin{array}{c}\text { Incremental } \\
\text { method }\end{array}$} & \multicolumn{2}{|c|}{$\begin{array}{c}\text { Functional } \\
\text { method }\end{array}$} \\
\hline & 86 & 869 & 86 & 869 & 86 & 869 & 86 & 869 \\
\hline प $R O E$ & -0.0096 & 0.0277 & -0.0096 & 0.0277 & -0.0096 & 0.0277 & -0.0096 & 0.0277 \\
\hline ROS & 0.0179 & 0.0007 & 0.0189 & 0.0006 & 0.0189 & 0.0006 & -0.0000 & 0.0007 \\
\hline$T A$ & -0.0103 & 0.0055 & -0.0110 & 0.0050 & -0.0110 & 0.0050 & 0.0004 & 0.0055 \\
\hline$F L$ & -0.0172 & 0.0216 & -0.0175 & 0.0221 & -0.0170 & 0.0210 & -0.0100 & 0.0216 \\
\hline Combined effect & - & & - & & 0.0013 & -0.0012 & - & \\
\hline
\end{tabular}

Source: own calculations 


\section{JOURNAL OF TOURISM AND SERVICES}

Issue 20, volume 11, ISSN 1804-5650 (Online)

www.jots.cz

Table 7. Methods of quantification of the impact of determining factors within the NACE 869 (20162017)

\begin{tabular}{|l|c|c|c|c|}
\hline \multicolumn{1}{|c|}{ Factors } & Logarithmic method & Index method & Incremental method & Functional method \\
\hline $\mathbf{Q}$ ROE & 0.00310 & 0.00310 & 0.00310 & 0.00310 \\
\hline ROS & 0.01181 & 0.01232 & 0.01232 & 0.01186 \\
\hline$T A$ & -0.01877 & -0.01895 & -0.01692 & -0.01886 \\
\hline$F L$ & 0.01006 & 0.00973 & 0.01041 & 0.01022 \\
\hline Combined effect & - & - & 0.00271 & - \\
\hline
\end{tabular}

The Du Pont model shows that in the period 2014-2015, in the NACE 869 industry, the positive change in return on equity (ROE) was mostly determined by indebtedness factor $(79.83 \%)$, where the coefficient of the financial leverage increased year-on-year from 1.22 to 1.47. Positive increase of the total assets turnover ratio contributed to increasing ROE by $17.97 \%$. Factor ROS increased the return on equity by only $2.18 \%$.

In the period 2016-2017, we recorded a slight growth rate of ROE that is the economic criterion of the effectiveness. Total assets turnover ratio $(T A)$ was the biggest contributor to the change of $\mathrm{ROE}$, while the property went through its stages of circulation for the fiscal year 1.06 times. In 2016, the total assets turnover ratio was 1.27. According to the logarithmic method, financial indicator $T A$ participated in reducing ROE by $605.46 \%$, according to the index method it was $611.37 \%$, according to the incremental method it was $545.67 \%$, and according to functional method financial indicator $T A$ participated in reducing ROE by $608.51 \%$. The increase in the growth rate of ROS by $12.04 \%$ increased ROE by up to $397.35 \%$.

\subsection{Assessing the Financial Situation of the Slovak Spa Companies}

In Table 8, we report an absolute impacts of four analytical indicators, namely $R O S\left(\Delta X_{R O S}\right)$, $T A\left(\Delta X_{T A}\right), F L\left(\Delta X_{F L}\right), E A T / E B I T\left(\Delta X_{E E}\right)$, on synthetic indicator ROE of the Slovak spa companies in the period 2017-2018. We provide the quantification of the impact of these four factors on the return on equity by using the functional method. In the given period, return on sales (ROS) was the largest contributor to the change of ROE within 8 of all analysed spa companies $(38.09 \%)$, in the second place, this indicator placed within 3 spa companies (14.28\%), in the third place, it influenced none of the given subjects, and in the fourth place, ROS contributed to the change of ROE within 10 subjects $(47.62 \%)$. Total assets turnover ratio (TA) mostly determined 2 spa companies (Spa Bojnice, a.s.; Spa Horný Smokovec, s.r.o.). Within 9 companies, it was identified as the second largest determinant (42.85\%), within 7 companies, as the third determinant $(33.33 \%)$, and within 3 companies, as the fourth determinant $(14.28 \%)$. Financial leverage $(F L)$ was the largest contributor to the overall change of ROE within 5 spa companies $(23.80 \%)$, in the second place was placed within 6 companies $(28.57 \%)$. FL was identified within 5 companies as the third largest determinant, and within 5 spa companies as the fourth.

Table 8. Quantification of the impact of determining factors within Slovak spa companies (2017-2018)

\begin{tabular}{|l|c|c|c|c|c|}
\hline \multicolumn{1}{|c|}{ Spa company } & $\boldsymbol{\Delta R O E}$ & Impact of $\boldsymbol{R O S}$ & Impact of $\boldsymbol{T A}$ & Impact of $\boldsymbol{F L}$ & Impact of $\boldsymbol{E E}$ \\
\hline Slovak Health Spa Piešt'any, a.s. & 0.0038 & -0.0017 & 0.0003 & -0.0012 & 0.0064 \\
\hline Slovak Health Spa Turčianske Teplice, a.s. & -0.0992 & -0.0857 & -0.0025 & -0.0007 & -0.0105 \\
\hline Slovak Health Spa Rajecké Teplice, a.s. & -0.0022 & -0.0096 & 0.0017 & -0.0001 & 0.0058 \\
\hline Bardejov Spa, a.s. & 0.0283 & 0.0211 & 0.0062 & -0.0032 & 0.0042 \\
\hline Spa Trenčianske Teplice, a.s. & 0.0016 & 0.0012 & 0.0002 & 0.0000 & 0.0002 \\
\hline
\end{tabular}


JOURNAL OF TOURISM AND SERVICES

Issue 20, volume 11, ISSN 1804-5650 (Online)

www.jots.cz

\begin{tabular}{|l|c|c|c|c|c|}
\hline Spa Bojnice, a.s. & -0.0046 & -0.0049 & 0.0007 & -0.0002 & -0.0002 \\
\hline Spa Dudince, a.s. & -0.0139 & -0.0112 & 0.0065 & -0.0046 & -0.0046 \\
\hline Spa Lúčky, a.s. & -0.0740 & -0.0473 & -0.0025 & 0.0071 & -0.0312 \\
\hline Spa Nimnica, a.s. & 0.0233 & 0.0257 & -0.0017 & -0.0013 & 0.0007 \\
\hline Specialized Medical Institute Marína, s.o. & -0.0089 & -0.0086 & -0.0004 & 0.0001 & 0.0000 \\
\hline Spa Vyšné Ružbachy, a.s. & -0.0199 & 0.0159 & -0.0002 & 0.0001 & -0.0356 \\
\hline Spa Lučivná, a.s. & -0.0008 & 0.0141 & 0.0042 & -0.0028 & -0.0162 \\
\hline Spa Sliač, a.s. & 0.0247 & 0.0102 & -0.0310 & 0.0367 & 0.0088 \\
\hline Slovthermae Spa Diamant, Dudince, s.o. & -0.0311 & -0.0451 & -0.0006 & -0.0004 & 0.0150 \\
\hline Spa Nový Smokovec, a.s. & 0.0052 & 0.0018 & 0.0012 & 0.0003 & 0.0020 \\
\hline Natural Iodine Spa Číž, a.s. & -7.5464 & 0.4410 & -0.8297 & -7.1613 & 0.0036 \\
\hline Spa Brusno, a.s. & -0.2477 & -0.2570 & -0.0844 & -0.0093 & 0.1030 \\
\hline Spa Štós, a.s. & 0.1424 & 0.1043 & -0.0265 & 0.0087 & 0.0558 \\
\hline Spa Kováčová, s.r.o. & -0.2910 & 0.4197 & -0.0005 & 0.0026 & -0.7127 \\
\hline Spa Horný Smokovec, s.r.o. & -0.0270 & -0.0195 & 0.0003 & -0.0036 & -0.0043 \\
\hline PIENINY RESORT, s.r.o. & -0.0073 & -0.0017 & 0.0134 & -0.0116 & -0.0074 \\
\hline
\end{tabular}

Source: own calculations

In Figure 2, we model the financial position of the Slovak spa companies in space in 2017, while we use MDS based on four financial ratios of productivity and costs, namely $R O A, R O S$, the ratio of personal costs to net turnover $(P C / S)$, the ratio of added value to sales $(A V / S)$. Figure 3 presents it for 2018. Both figures contain of configuration A and B. Configuration B shows MDS only for 20 spa companies, specifically without Specialized Medical Institute Marína, s.o., because this spa has extreme position. Moreover, Table 9 displays values of calculated Kruskal's Stress for both figures and both configurations.

Figure 2. MDS for 2017 (Configuration A - all spa companies; Configuration B - without Specialized Medical Institute Marína)
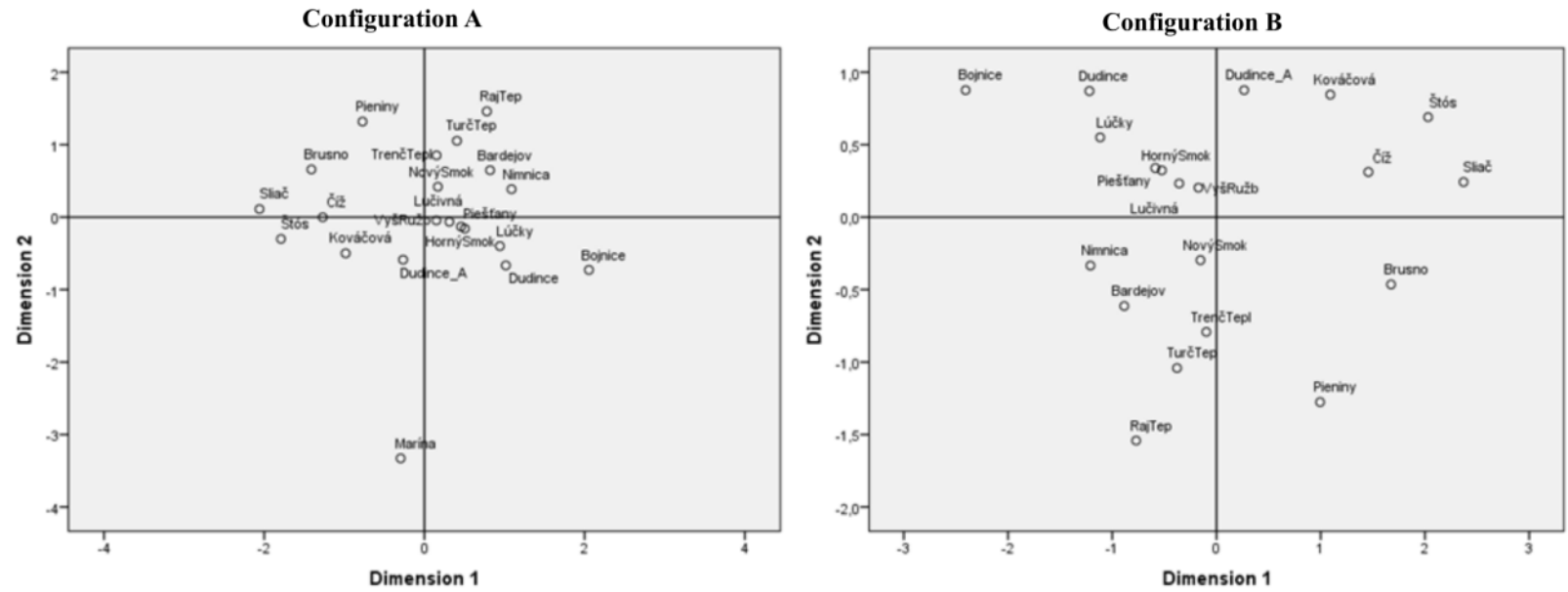

Source: own processing using figures from SPSS

Figure 3. MDS for 2018 (Configuration A - all spa companies; Configuration B - without Specialized Medical Institute Marína) 


\section{JOURNAL OF TOURISM AND SERVICES}

Issue 20, volume 11, ISSN 1804-5650 (Online)

www.jots.cz
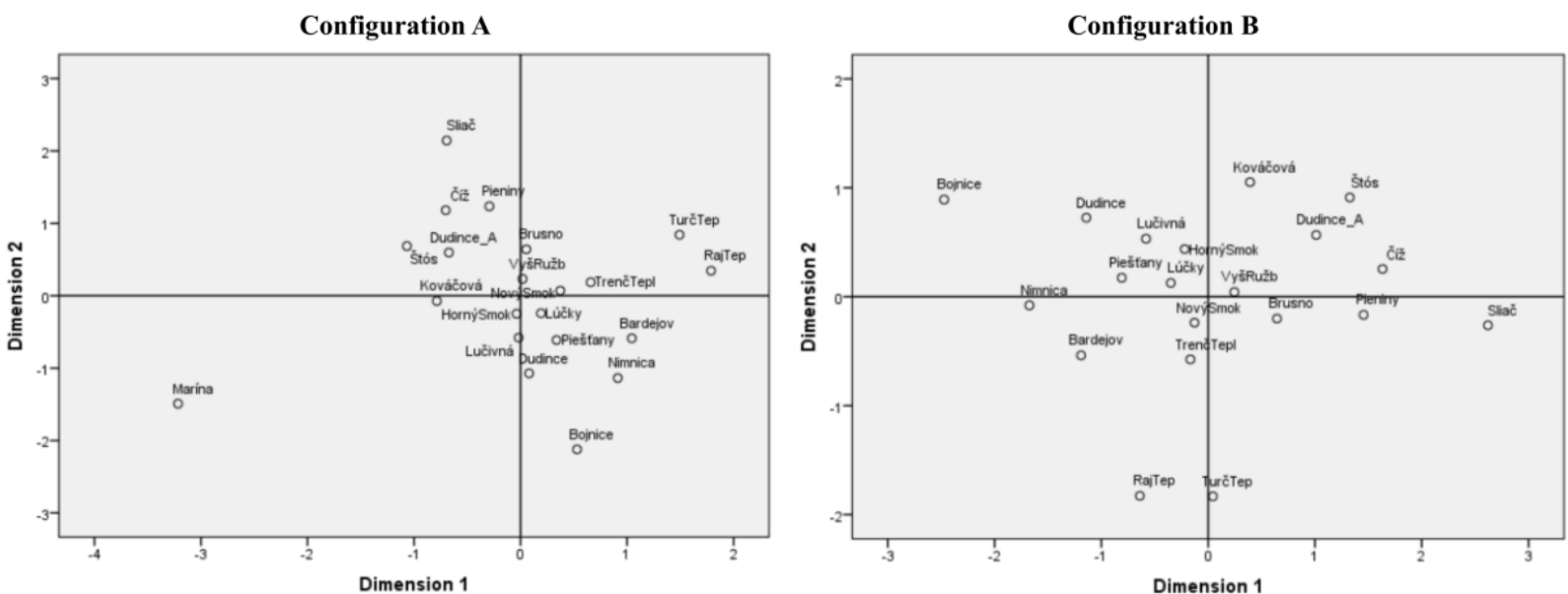

Source: own processing using figures from SPSS

Table 9. Values of Kruskal's Stress

\begin{tabular}{|l|c|c|}
\hline & Stress Configuration A & Stress Configuration B \\
\hline Figure 2 - 2017 (4 financial indicators) & 0.03329 & 0.03918 \\
\hline Figure 3-2018 (4 financial indicators) & 0.02800 & 0.03312 \\
\hline
\end{tabular}

Source: own calculations in SPSS

We also apply MDS by using 5 financial indicators, namely $\mathrm{ROA}, \mathrm{ROS}$, the ratio of personal costs to net turnover, the ratio of added value to sales, and debt ratio. The debt ratio indicates whether the company is in crisis or at risk of crisis. Figure 4 presents the results of MDS.

Figure 4. MDS for 2018 - 5 financial indicators (Configuration A - all spa companies; Configuration B without Spa Bojnice and Specialized Medical Institute Marína)
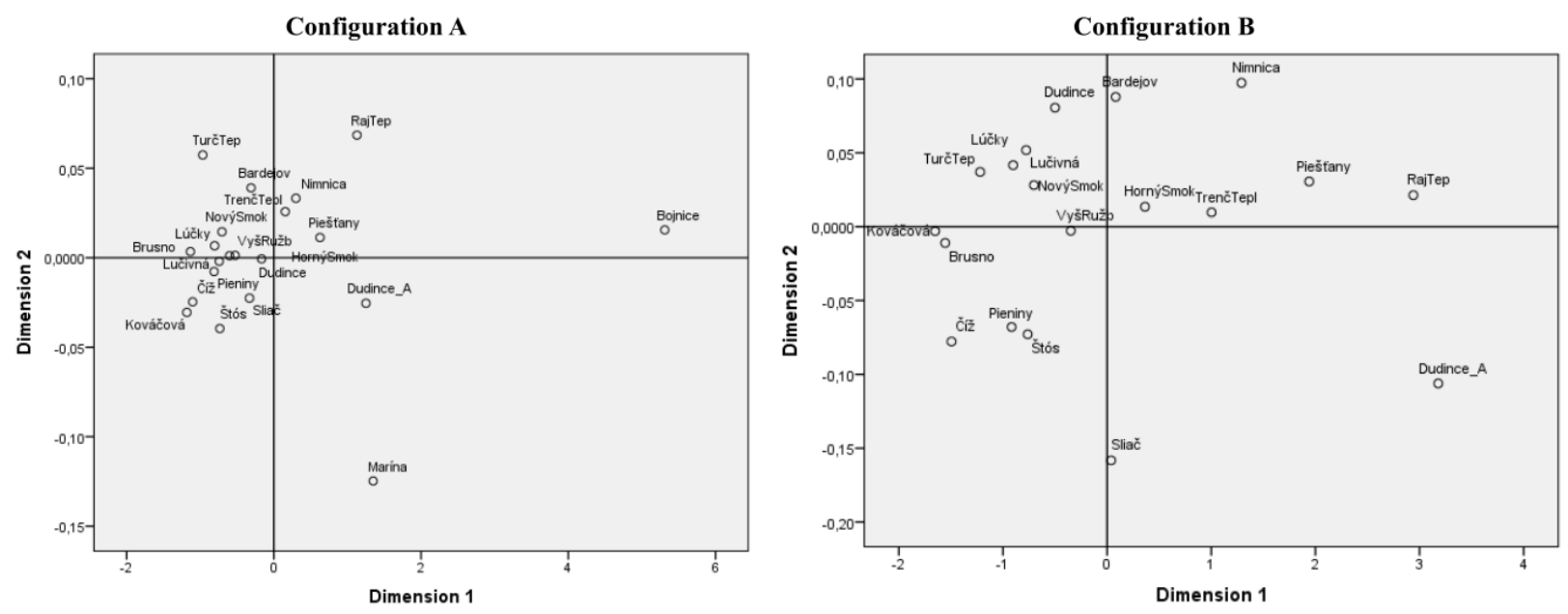

Source: own processing using figures from SPSS

Section 67a of the Act No. 513/1991 Coll. the Commercial Code defines that the company is in crisis if it is bankrupt or is threatened by bankruptcy. A company is threatened by bankruptcy if the ratio of its equity and liabilities is less than 8. In 2018, Spa Bojnice, a.s has extreme position because the amount of equity (34.142 $\mathrm{M} €$ ) exceeded foreign capital 23.03 times and overall indebtedness ware 


\section{JOURNAL OF TOURISM AND SERVICES}

Issue 20, volume 11, ISSN 1804-5650 (Online)

www.jots.cz

4.16\%. In Configuration B of the Figure 4, we model MDS diagram without two spa companies, which recorded extreme values (Spa Bojnice, a.s, and Specialized Medical Institute Marína, s.o.).

\section{Conclusion}

This paper provided a significant explanatory power of the financial position in space using the multidimensional scaling method, in which the criteria were selected on the basis of consultation with financial managers of several spa companies. Our results are valuable for managers' decision-making, while our contribution is: i) application of methods of quantifying the impact of three cardinal determining factors on the return on equity in two groups of decision-making units, specifically in overall Slovak health care industry (NACE 86) and in its subindustry (NACE 869); ii) quantifying the four factors of Du Pont model among Slovak spa companies.

In this paper, among two groups of decision-making units within the overall Slovak health industry and its one sub-industry, we provide quantification of the impact of three cardinal factors on the return on equity. Moreover, we quantify four factors for the spa companies operating in Slovakia. By implementing several mathematical methods, there are assessed and compared the impacts of individual areas of financial management on the overall return on equity of the healthcare decisionmaking units. Results of the analysis connected with NACE 86 and 869 financial situations show that during the analysing period, ROE was mostly determined by indebtedness factor, and then by assets utilization. The operating profit margin determines ROE to the smallest extent. According to the financial and economic position of individual spa companies, in the long-term perspective, Spa Bojnice, a.s. reached the best results. On the other hand, Spa Brusno, a.s. (restructuring) has a negative position, and therefore, it is at risk of total demise even though it still provides spa services to its guests. Its demise will have negative consequences for the tourism in Slovakia, but also for international trade, which will affect the export of mineral water to Russia. In fact, Russia is directly dependent on Spa Brusno, a.s.

Owners of the companies and managers need to very carefully study the factors that affect their business to achieve maximisation of a company value (Blažková, 2018). They should also pay attention on whole tourism supply chain to be successful (Slusarczyk, Smolag and Kot, 2016). The results of this study provide an analytical view of the financial situation and position of the Slovak spa industry (since the establishment of SK NACE), what provide benefits and enrichment for experts in the field of finance, healthcare, tourism and spa tourism.

When monitoring particular impacts, the individual components are not given their importance. Therefore, in this sector, financial managers of decision-making units should consider including weights when applying appropriate pyramid modeling methods (within additive, multiplicative, or combined linkages). The use of pyramid systems is not applied in practice a lot because it is a complex and logical tool perceiving causality. Authors of financial models believe that low usage rate is determined by higher difficulty and the unwillingness of corporate practice to accept more difficult solutions and models requiring inventions (Kislingerová, 2014). Within quantifying the impact of determining factors, the aim of further research will be assigning weights to individual indicators (criterions) as it would be appropriate to consider a multi-criteria evaluation of the financial level of business entities according to established preferences. It might be interesting to apply advanced methods of the statistical analysis of multidimensional data when we will assess the financial position of business entities in space (e.g., PCA or cluster analysis).

Because of the adoption of new support measures in the field of tourism, an increase in the number of arrivals of domestic visitors to the spas was expected in 2019 (Jenčová and Vašaničová, 2019). Given the situation regarding the spread of the new coronavirus COVID-19, these expectations and forecasts are no longer relevant. With the introduction of several measures by the Government of the Slovak 


\section{JOURNAL OF TOURISM AND SERVICES}

Issue 20, volume 11, ISSN 1804-5650 (Online)

www.jots.cz

Republic, some spas temporarily interrupted their operation as a precaution even though they didn't have to. The negative effects that cause high economic losses to the spa are an obstacle to a successfully developing industry in the country. This industry expects necessary state assistance, but on the other hand, spa companies can provide accommodation to the state for quarantine.

\section{Acknowledgement}

This work was supported by the Slovak Research and Development Agency under the contract no. APVV-17-0166. Moreover, this work was supported by research grant GAPU 43/2019 "Kultúrne rozdiely a ich vplyv na cestovný ruch (Cultural differences and their impact on tourism)".

\section{References}

1. Act No. 513/1991 Coll. the Commercial Code as amended.

2. Benda-Prokeinová, R., Dobeš, K., Mura, L., Buleca, J. (2017). Engel's Approach as a tool for estimating consumer behaviour. E \& $M$ Ekonomie a Management, 20 (2), pp. 15 - 29. doi: $10.15240 / \mathrm{tul} / 001 / 2017-2-002$

3. Blažková, I. (2018). Sectoral and Firm-Level Determinants of Profitability: A Multilevel Approach. International Journal of Entrepreneurial Knowledge, 6(2), 32-44.

4. Cuka, P., Rachwal, T. (2013). Economic, touristic and therapentic potential of natural water springs in Slovakia. Surveying Geology \& mining Ecology Management International Multidisciplinary Scientific GeoConference: SGEM, Albena, Bulgaria. doi: 10.5593/SGEM2013/BE5.V2/S21.012.

5. Čabinová, V., Onuferová, E. (2019a). Designing an advanced PPE model to measure performance and efficiency of Slovak spa enterprises. Scientific papers of the University of Pardubice, 46, 30-43.

6. Čabinová, V., Onuferová, E. (2019b). Efficiency and Financial Performance Evaluation of the Medical Spa Sector: An Empirical Study from Slovakia. Calitatea, 20(172), 62-68.

7. Derco, J., Pavlisinova, D. (2017). Financial position of medical spas - The case of Slovakia. Tourism Economics, 23(4), 867-873.

8. Gallo, P., et al. (2018). Importance of Financial and Non-financial Indicators in Companies with the Balanced Scorecard Concept. Quality - Access to Success, 19(165), 34-38.

9. Jašková, D. (2019). Assessment of social development in Slovakia in the context of human resources. Central European Journal of Labour Law and Personnel Management, 2 (2), 21-32. doi:10.33382/cejllpm.2019.03.02

10. Jenčová, S. (2016). Finančno-ekonomická analýza podnikatelských subjektov. Prešov: Bookman.

11. Jenčová, S., et al. (2018). Competitiveness of spa companies. Management 2018. International Scientific Conference, Nový Smokovec, Slovak Republic.

12. Jenčová, S., Litavcová, E., Vašaničová, P. (2017). Aplikácia viacrozmených metód v odvetví zdravotníctva. Zborník abstraktov a príspevkov z konferencie Nitrianske štatistické dni 2017, Bratislava, Slovak Republic.

13. Jenčová, S., Vašaničová, P. (2019). Profitability of Slovak spa industry. Journal of Management and Business: Research and Practice, 11(2), 30-35.

14. Jenčová, S., Vašaničová, P., Petruška, I. (2019). Financial Position of the Slovak Spa Companies. European Financial Systems. Proceedings of the 16th International Scientific Conference, Brno, Czech Republic. 


\section{JOURNAL OF TOURISM AND SERVICES}

Issue 20, volume 11, ISSN 1804-5650 (Online)

www.jots.cz

15. Jenčová, S., Vašaničová, P., Litavcová, E. (2019). Financial indicators of the company from electrical engineering industry: The case study of Tesla, Inc. Serbian Journal of Management, 15(4), 361-371. doi: 10.5937/sjm14-15692.

16. Kasagranda, A., Gurňák, D. (2017). Spa and wellness tourism in Slovakia (A geographical analysis). Crech Journal of Tourism, 6(1), 27-53.

17. Kerekeš, J. (2018). Kúpelníctvo a jebo význam v turiz̨me. Bratislava, Weltprint.

18. Kerekeš, J. (2014). Vỹznam a prínos kúpelnébo turižmu pre Slovensko, Piešt'any, Fakulta cestovného ruchu.

19. Kislingerová, E., et al. (2014). Nové trendy ve vývoji konkurencieschopnosti podnikù Céeskej republikey. Praha: C.H. Beck.

20. Kliestik, T., et al. (2020). Remaining Financially Healthy and Competitive: The Role of Financial Predictors. Journal of Competitiveness, 12(1), 74-92.

21. Kliestik, T., Misankova, M., Valaskova, K., \& Svabova, L. (2018). Bankruptcy prevention: new effort to reflect on legal and social changes. Science and Engineering Ethics, 24(2), 791-803.

22. Košíková, M., Loumová, V. (2019a). Posúdenie vývoja kúpelnébo cestovnébo ruchu s dôrazom jeho uplyvu na cestovný ruch Slovenskej republiky. Predikčná analýza finančnej situácie nefinančných korporácií: Konferenčný zborník príspevkov, Prešov, Slovak Republic.

23. Košíková, M., Loumová, V. (2019b). Spa Economy, Wellness Tourism, Thermal/Mineral Springs analýra rozdielov a postavenie kúpelnictva a kúpelnébo cestovnébo ruchu vo svetovom ponímaní. Ekomická aktivita turizmu: Nekonferenčný zborník príspevkov, Prešov, Slovak Republic.

24. Košíková, M., Šenková, A. (2019). Spokojnost návštevníkov s kúpelnými službami. Modelovanie environmentálneho manažérstva a Ekonomická aktivita turizmu v Európskom priestore: Nekonferenčný zborník príspevkov. Prešovská univerzita v Prešove, Prešov, Slovak Republic.

25. Kovacova, M., Kliestik, T., Valaskova, K., Durana, P., \& Juhaszova, Z. (2019). Systematic review of variables applied in bankruptcy prediction models of Visegrad group countries. Oeconomia Copernicana, 10(4), 743-772.

26. Kruskal, J. B., Carmone, F. J. (1967). How to use MDSCAL (version 5M) and other useful information. Bell Laboratories, Unpulished manuscript.

27. Kučerova, J. (2013). Impact of Economic Crisis on the Spa Businesses in Slovakia. Tourism in Southern and Eastern Europe. 2nd International Scientific Conference Tourism in South East Europe 2013, Opatija, Croatia.

28. Litavcová, E., et al. (2018). Implementation of Multidimensional Analytical Methods to Compare Performance between Spa Facilities. The 12th International Days of Statistics and Economics, Prague, Czech Republic.

29. Matlovičová K., Kolesárová, J., Židová, A. (2013). Slovak spas in the context of change - current conditions, issues and challenges. Recreational use of geothermal water in Visegrad Group countries, Kraków, Poland.

30. Meloun, M., et al. (2017). Statistická analyźa vícerozmèrmých dat v príkladech. Praha: Univerzita Karlova.

31. Onuferová, E., Čabinová, V., Dzurov Vargová, T. (2020). Analysis of modern methods for increasing and managing the financial prosperity of businesses in the context of performance: a case study of the tourism sector in Slovakia. Oeconomia Copernicana, 11(1), 95-116.

32. Pauhofova, I., Stehlikova, B, Kljucnikov, A. \& Androniceanu, A. (2018). Spatial and sectoral conditionality of the average monthly nominal wage in the Slovak Republic, Transformations in Business and Economics, 17(3), 155-168.

33. Petruška, I. (2017). Analýza ukazovatelov cestovného ruchu krajín EÚ pomocou multidimenzionálneho škálovania. Ekomická aktivita turizmu: Nekonferenčný zborník príspevkov. Prešov, Slovak Republic. 


\section{JOURNAL OF TOURISM AND SERVICES}

Issue 20, volume 11, ISSN 1804-5650 (Online)

www.jots.cz

34. Slusarczyk, B., Smolag, K., Kot, S. (2016). The supply chain of a tourism product. Actual Problems of Economics, 179 (5), 197-207.

35. Štefko, R. et al. (2017). Management and Funding of the Healthcare System. Polish Journal of Management Studies, 16(2), 266-277. doi: 10.17512/pjms.2017.16.2.23.

36. Vašaničová, P. (2018). Cestovný ruch a ubytovacie zariadenia Slovenska. Motívy účast' a analýza návštevnosti. Prešov: Prešovská uviverzita v Prešove.

37. Vrbka, J., Nica, E., \& Podhorská, I. (2019). The application of Kohonen networks for identification of leaders in the trade sector in Czechia. Equilibrium. Quarterly Journal of Economics and Economic Policy, 14(4), 739-761. doi:10.24136/eq.2019.034

38. Zimon, G. (2018). Influence of group purchasing organizations on financial situation of Polish SMEs. Oeconomia Copernicana, 9(1), 87-104. doi:10.24136/oc.2018.005

39. Zmeškal, Z., Dluhošová, D., Tichý, T. (2013). Finančni modely. Koncepty, metody, aplikace. Praha: Ekopress.

\section{Brief description of Authors:}

\section{prof. Ing. Róbert Štefko, Ph.D.}

Department of Marketing and International Trade, Faculty of Management, University of Prešov, Konštantínova 16, 08001 Prešov, Slovakia,www.unipo.sk/fm, email: robert.stefko@unipo.sk. Róbert Stefko is the Dean of the Faculty of Management of University of Prešov. In the economic field of study Management, he is the guarantor of bachelor's, master's and doctoral study programmes. Up to now, he has been a member of nine faculty and university scientific boards (seven faculty and two university scientific boards) at universities in the Czech Republic, Slovakia and Poland. He is the Chairperson of the Scientific Board of the Faculty of Management of University of Prešov.

\section{doc. Ing. Sylvia Jenčová, PhD.}

Department of Finance, Faculty of Management, University of Prešov, Konštantínova 16, 08001 Prešov, Slovakia, www.unipo.sk/fm, email: sylvia.jencova@unipo.sk. Sylvia Jenčová is an Associate professor in the Department of Finance, Faculty of Management, University of Prešov, since 2008. Her scientific research (with publication) is focused on financial analysis, primarily in the area of financial management, financial modeling, managerial economics, and is dedicated to an assay method, as well as selected macroeconomic problems. She lectured in Managerial Economics and International Trade and Business at the Business Institute in Prague.

\section{PhDr. Petra Vašaničová, PhD.}

Department of Mathematical Methods and Managerial Informatics, Faculty of Management, University of Prešov, Konštantínova 16, 08001 Prešov, Slovakia, www.unipo.sk/fm, email: petra.vasanicova@unipo.sk. Petra Vašaničová is a lecturer at the Faculty of Management, University of Prešov. Her research interest is the study of how tourism activity among European countries is interconnected with each other, how to predict the financial distress of companies in the tourism sector and how can network theory help us to understand the interconnectedness of tourism activity in Europe. 